\title{
Biomass and Species Diversity of Different Alpine Plant Communities Respond Differently to Nitrogen Deposition and Experimental Warming
}

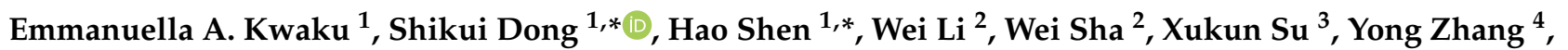 \\ Shuai $\mathrm{Li}^{2}$, Xiaoxia Gao ${ }^{2}$, Shiliang Liu ${ }^{2} \oplus$, Jianbin $\mathrm{Shi}^{2}$, Xiaowen $\mathrm{Li}^{2}$, Quanru Liu ${ }^{5}$ and Zhenzhen Zhao ${ }^{6, *}$
}

Citation: Kwaku, E.A.; Dong, S.; Shen, H.; Li, W.; Sha, W.; Su, X.; Zhang, Y.; Li, S.; Gao, X.; Liu, S.; et al. Biomass and Species Diversity of Different Alpine Plant Communities Respond Differently to Nitrogen Deposition and Experimental Warming. Plants 2021, 10, 2719. https://doi.org/10.3390/ plants10122719

Academic Editors: Peili Shi, Jian Sun, Huakun Zhou and Jianshuang $\mathrm{Wu}$

Received: 6 October 2021

Accepted: 30 November 2021

Published: 10 December 2021

Publisher's Note: MDPI stays neutral with regard to jurisdictional claims in published maps and institutional affiliations.

Copyright: (c) 2021 by the authors. Licensee MDPI, Basel, Switzerland. This article is an open access article distributed under the terms and conditions of the Creative Commons Attribution (CC BY) license (https:/ / creativecommons.org/licenses/by/ $4.0 /)$.
1 School of Grassland Science, Beijing Forestry University, Beijing 100083, China; emmkwaku.17@gmail.com

2 State Key Joint Laboratory of Environmental Sanitation and Pollution Control, School of Environment, Beijing Normal University, Beijing 100875, China; weili@bnu.edu.cn (W.L.); weisha@pku.edu.cn (W.S.); shuaili@sxau.edu.cn (S.L.); gaoxiaoxia0113@163.com (X.G.); shiliangliu@bnu.edu.cn (S.L.); jbshi@bnu.edu.cn (J.S.); xwli_bnu@163.com (X.L.)

3 Research Center for Eco-Environment, Chinese Academy of Sciences, Beijing 100085, China; suxukun1985@163.com

4 National Plateau Wetland Research Center, College of Wetlands, Southwest Forestry University, Kunming 650224, China; zhy1902@126.com

5 School of Life Sciences, Beijing Normal University, Beijing 100875, China; liuquanru@bnu.edu.cn

6 School of Environmental and Chemical Engineering, Shanghai University, Shanghai 200444, China

* Correspondence: dongshikui@bjfu.edu.cn (S.D.); shenhao2222@gmail.com (H.S.); zzz0828@shu.edu.cn (Z.Z.)
Abstract: The ability of fragile ecosystems of alpine regions to adapt and thrive under warming and nitrogen deposition is a pressing conservation concern. The lack of information on how these ecosystems respond to the combined impacts of elevated levels of nitrogen and a warming climate limits the sustainable management approaches of alpine grasslands. In this study, we experimented using a completely random blocked design to examine the effects of warming and nitrogen deposition on the aboveground biomass and diversity of alpine grassland plant communities. The experiment was carried out from 2015 to 2018 in four vegetation types, e.g., alpine desert, alpine desert steppe, alpine marsh, and alpine salinised meadow, in the Aerjin Mountain Nature Reserve (AMNR) on the Qinghai-Tibetan Plateau (QTP). We found that W (warming) and WN (warming plus N deposition) treatment significantly increased the aboveground biomass of all the vegetation types $(p<0.05)$ in 2018. However, W and WN treatment only significantly increased the Shannon diversity of salinised meadows in 2018 and had no significant effect on the Shannon diversity of other vegetation types. Such results suggested that long-term nitrogen deposition and warming can consistently stimulate biomass accumulation of the alpine plant communities. Compared with other vegetation types, the diversity of alpine salinised meadows are generally more susceptible to long-term warming and warming combined with $\mathrm{N}$ deposition. Warming accounts many of such variabilities, while short-term $\mathrm{N}$ deposition alone may not significantly have an evident effect on the productivity and diversity of alpine grasslands. Our findings suggested that the effects of short-term ( $\leq 4$ years) $\mathrm{N}$ deposition on alpine vegetation productivity and diversity were minimal, while long-term warming (>4 years) will be much more favourable for alpine vegetation.

Keywords: nitrogen addition; warming; diversity; productivity; alpine grasslands

\section{Introduction}

The global surface temperature is expected to increase by about $4{ }^{\circ} \mathrm{C}$ by 2100 [1]. Parallel to these warming trends is the dramatic increase in anthropogenic nitrogen emission and deposition on a global scale [2]. This can influence critical ecological processes, including range and structural shifts in plant species [3]. Under growing effects of global 
environmental changes, it is important to understand the response of vegetation to the combined effects of warming and nitrogen deposition.

Previous studies have found that temperature can modify nitrogen mineralisation [4,5], which is often exacerbated by changes in land use [6-8]. Some studies found that the number of vascular plants generally tends to increase with the increase in temperature and nitrogen deposition; this may be because temperature and nutrients are the main limiting factors in alpine ecosystems [9]. However, plant community and plant species might respond differently to nitrogen deposition due to variations in nitrogen use efficiency or their differential adaptability $[10,11]$. The general findings of previous studies indicated a decline in species richness in various ecosystems such as acidic, saline mountain and temperate grasslands [12-14]. The results regarding the effects of increased nitrogen deposition on plants biomass and diversity vary; positive, neutral and negative findings have been reported [15-18]. Plant species richness is an important indicator for diversity, and a previous study found that species richness might decline as a result of increased nitrogen deposition [19]. $\mathrm{N}$ deposition has the potential to decrease plant richness by favouring the plant species that can better adapt to high nutrient loads [19]. Under high $\mathrm{N}$ deposition, numbers of nitrophilous plant species may increase, while numbers of $\mathrm{N}$ sensitive plant species may decrease. Additionally, N deposition can cause soil acidification, which will impact plant growth and thus cause species loss.

Warming and nitrogen deposition have impacted ecosystem multi-functionalities and contributed to the global carbon budget [20]. These synergistic effects bring big challenges to the grassland conservation domain [21,22]; previous experiments have demonstrated warming and nitrogen deposition stimulate plants biomass and enhance the photosynthetic abilities of key plants [23-25]. The effects of elevated nitrogen deposition on plants can also be distinguishable by drier months and at the species level [23]. Warming and nitrogen deposition significantly increased plant community composition, diversity and richness due to long-term increases in temperature and nitrogen deposition levels [11]. Previous results about warming effects on plant biomass are not consistent, because positive [26], negative [27] and neutral [28] results were found. So far, the extent to which alpine vegetation responds and serves as a sink for nitrogen under climate (temperature) variability is poorly studied. Understanding further how alpine vegetation responds to nitrogen deposition and increased temperature is essential for conservation efforts for fragile alpine ecosystems.

The QTP is considered the "third pole" and a key alpine biome in the world [29-31]. The alpine vegetation on the QTP is highly sensitive to nitrogen deposition and warming [32-34]. Several key experiments have been performed across the QTP to quantify the extent of warming and nitrogen influences on alpine plant productivity [35-39]. However, most investigations regarding warming and nitrogen deposition did not account for how different vegetation types respond to warming and $\mathrm{N}$ deposition at the same time and sites. Here, we assess the synergistic effects of simulated warming and nitrogen deposition on plant productivity and diversity across different vegetation types and over 4 years to inform global environmental change policies. The operating hypotheses for this study are that: (1) the duration of warming and nitrogen addition would influence plant species diversity and aboveground biomass and (2) the effect of warming and nitrogen addition differs across different vegetation types, including alpine desert, alpine desert steppe, alpine marsh and alpine salinised meadow. The sensitivity of plants to the combined effects of warming and nitrogen is important for devising sustainable conservation management efforts and enhances our understanding of responses of alpine vegetation to global environmental changes.

\section{Materials and Methods}

\subsection{Study Sites and Experimental Treatment}

The study was conducted in the Aerjin Mountain Nature Reserve (AMNR), which is located in the northwestern QTP at $87^{\circ} 10^{\prime} 18^{\prime \prime}-91^{\circ} \mathrm{E}$, and $36^{\circ} 00^{\prime} 49^{\prime \prime}-37^{\circ} \mathrm{N}$. The QTP has a 
total land size of 2.6 million $\mathrm{km}^{2}$ and is on average $4000 \mathrm{~m}$ above mean sea level. It accounts for over $50-60 \%$ of the total carbon budget from grassland ecosystems in China [40]. The plateau has abundant and diverse species, making it one of the biodiversity conservation hotspots in China [41]. As a sustainable future is a goal, several tracts of the QTP are protected, including Aerjin Mountain, Changtang and the Hohxil National Nature Reserve. The Aerjin Mountain Nature Reserve (AMNR) has a land size of $45,000 \mathrm{~km}^{2}$ and it is surrounded by high mountains. The reserve has no frost-free periods. The climate is cold, dry and windy. The average temperature at the QTP has increased by about $0.3{ }^{\circ} \mathrm{C}$ per decade over the last 50 years, a rate that is faster compared to the average temperature of China [42], with an annual mean temperature below zero degrees and an average annual rainfall of about $300 \mathrm{~mm}$. According to the International Soil Classification system, the dominant soils in the AMNR are loam and loam-sandy. The major vegetation types in the AMNR are desert, desert steppe, marsh, salinised meadow and sparse alpine vegetation. The study was conducted on four different vegetation types. Salsola abrotanoides Bunge is the dominating species in the desert located in the southeastern AMNR, desert steppe is dominated by Stipa purpurea Griseb found in the southwestern AMNR, marsh is dominated by Kobresia robusta Maximowicz and Carex moorcroftii Falc. Ex Boott located around the rivers and lakes and Allium polyrhizum Turcz. ex Regel and Kalidium foliatum (Pall.) Moq. dominate in the salinised meadow around the edges of the south and north of the AMNR.

\subsection{Experimental Design}

To explore responses of alpine plant communities to experimental warming and nitrogen addition, we carried out complete randomised block experiments across four distinct vegetation types (hereafter "sites"), including marsh, salinised meadow, desert and desert steppe. For each type of vegetation, 12 plots (replicates) of $2 \mathrm{~m} \times 5 \mathrm{~m}$ were randomly placed. The plots were set up for four treatments: a control treatment without nitrogen and warming $(\mathrm{CK})$, a warming treatment $(\mathrm{W})$, a warming and nitrogen treatment $(\mathrm{WN})$ and a nitrogen treatment $(\mathrm{N})$. For the nitrogen addition treatment, a single level of ammonium nitrate $\left(\mathrm{NH}_{4} \mathrm{NO}_{3}\right)$ was applied (Figure 1). Given that the nitrogen deposition on the QTP is $8 \mathrm{~kg} \mathrm{~N} \mathrm{ha}^{-1}$ year $^{-1}$ as reported by Lü and Tian (2007) [29], we set the $\mathrm{N}$ to $16 \mathrm{~kg} \mathrm{~N} \mathrm{ha}^{-1}$ year $^{-1}$ to represent two times the annual $\mathrm{N}$ deposition on the QTP.

In the warming plot $(\mathrm{W})$, the temperature was elevated by approximately $1.8-2.2^{\circ} \mathrm{C}$ more than that of the control plot. During treatment application, three open-top chambers (OTCs, Figure S1) were placed randomly on W subplots. OTCs permit the quasi-natural transmittance of visible wavelengths and reduce the transmittance of reradiated infrared wavelengths [43]. The OTCs used in this study were comparable to the hexagonal chambers designed by Marion et al. (1997) [43] and consisted of transparent polycarbonate (50 $\mathrm{cm}$ high, $1.7 \mathrm{~m}$ at the top and $2.4 \mathrm{~m}$ at the base) [44]. The OTCs were elevated $10 \mathrm{~cm}$ above the soil surface to allow airflow [45]. The installation of OTCs in the field was carried out by adhering to the standard procedures of the International Tundra Experiment (ITEX) [46]. Soil temperature sensors (5TM; Decagon Devices, Pullman, WA, USA) were mounted at $5 \mathrm{~cm}$ depth in all the plots. The 5TM sensors (CR1000, Campbell Scientific; Logan, Utah; USA) recorded the temperature at $5 \mathrm{~s}$ intervals, after which an average value of $2 \mathrm{~min}$ was recorded [44]. The experiments were repeated for the 192 subplots ( 4 treatments $\times 3$ replicates $\times 4$ grassland types $\times 4$ years). The experiments were carried out at the peak of the growing season in late July to late August of 2015 to 2018

\subsection{Plant Productivity and Diversity Calculation}

The percentage of species, cover and richness were estimated by field visual observation according to Ren's methods (1998) [47]. We randomly placed one $1 \mathrm{~m} \times 1 \mathrm{~m}$ quadrat for the plant species composition survey, and species names, the number of species, plant heights and plant coverages were all recorded. During the peak growth season (July-August) in each year, the aboveground plant parts in each plot were harvested after investigation and dried at $70{ }^{\circ} \mathrm{C}$ in the lab for the measurement of aboveground 
biomass. Species richness was calculated as the total number of plants species in the plot. The relative abundance of each species was calculated as the ratio between individual species and the different treatment levels and the total number of species in the plots [47]. Shannon-Weiner's diversity index was used to quantify species diversity status in all the habitats [48]. The index assumes that individuals are randomly sampled from an 'infinitely large' population and all the species from a community are included in the sample. Species evenness relates to how abundantly the species occurs in the plant community, and it is related inversely to species dominance.

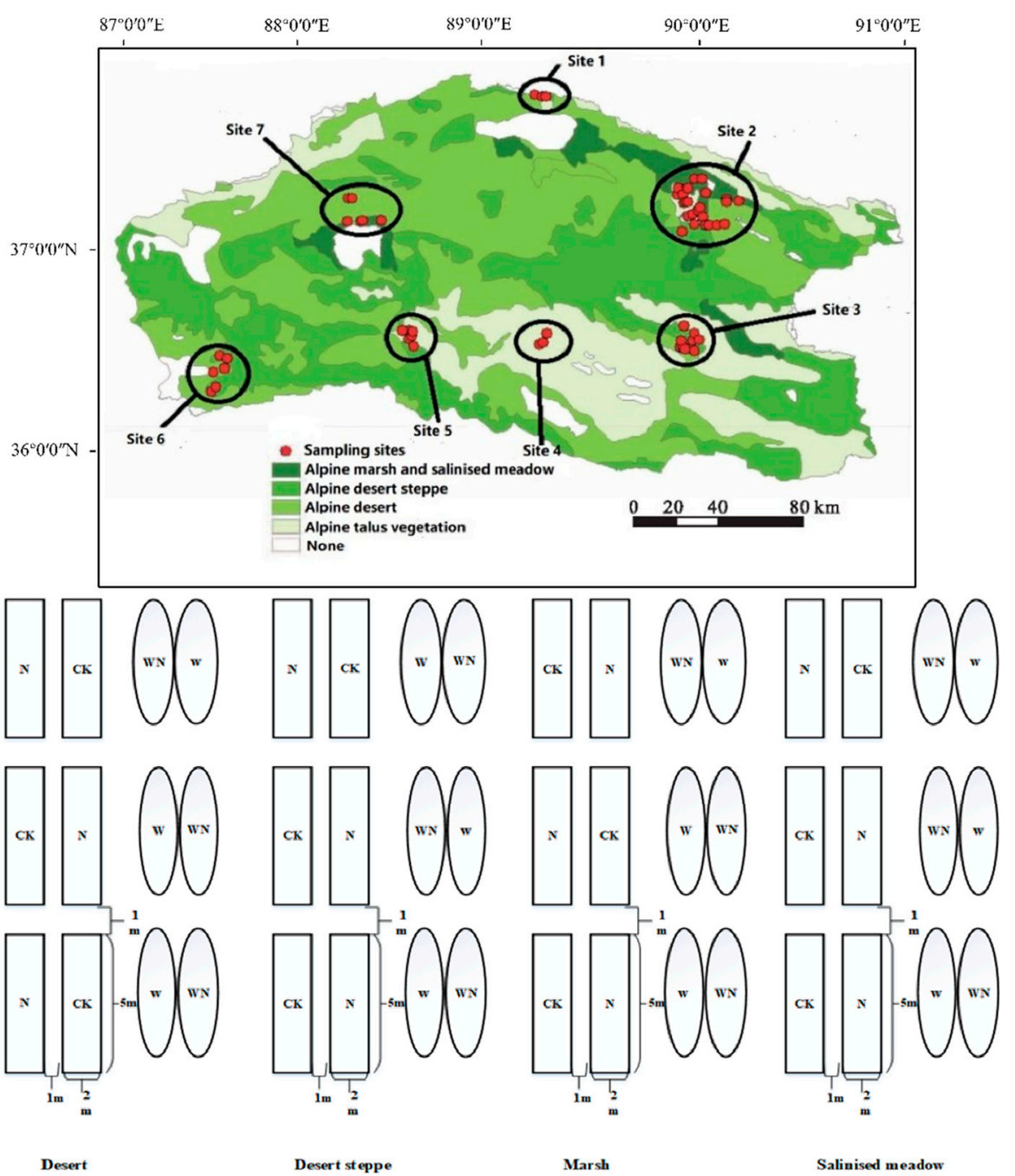

Figure 1. Main vegetation types, sampling sites and treatment in Aerjin Mountain Nature Reserve. The experimental plots: $\mathrm{CK}=$ no $\mathrm{N}$ addition, $\mathrm{N}=16 \mathrm{~kg} \mathrm{~N}^{-1}$ year $^{-1}, \mathrm{~W}=$ warming and $\mathrm{WN}=$ warming $+\mathrm{N}$ addition. The boxes and circles in this figure represent the shape of plots.

\subsection{Statistical Analysis}

Statistical analysis was performed with R 3.6.1. A two-way analysis of variance (ANOVA) was used to test the effects of the year, treatment and the interactions between year and treatment on the plant biomass, cover, height, richness, and diversity. The figure that displays the response of total community aboveground biomass and Shannon diversity to nitrogen addition and experimental warming in the desert (DST), desert steppe (DSP), marsh (MSH) and salinised meadow (SLM) from 2015 to 2018 was produced by Origin Pro 8.0 (OriginLab Corporation; Northampton, MA, USA). 


\section{Results}

\subsection{Effects of $N, W$ and $W N$ on Aboveground Plant Biomass and Plant Diversity}

The experimental treatments had varying effects on the aboveground plant biomass and plant diversity across vegetation types and sampling years (Figure 2). No significant differences of aboveground plant biomass were observed among different experimental treatments for all vegetation types in $2015(p>0.05)$ and $2017(p>0.05)$. In 2016, the aboveground biomass of the alpine desert steppe was significantly higher for WN compared to $C K(p<0.05)$. Compared with $C K$, the aboveground biomass was significantly higher in the $\mathrm{WN}$ and $\mathrm{N}$ treatments in the alpine salinised meadow $(p<0.05)$. In 2018 , the aboveground biomass was significantly higher in the $\mathrm{W}$ and $\mathrm{WN}$ treatments $(p<0.05)$ compared with CK in all the vegetation types. Significant differences in plant species diversity were not detected among the different experimental treatments for all vegetation types in $2015(p<0.05), 2016(p<0.05)$ and $2017(p<0.05)$. In 2018, the W and WN treatments significantly increased the Shannon diversity of the salinised meadow $(p<0.05)$.

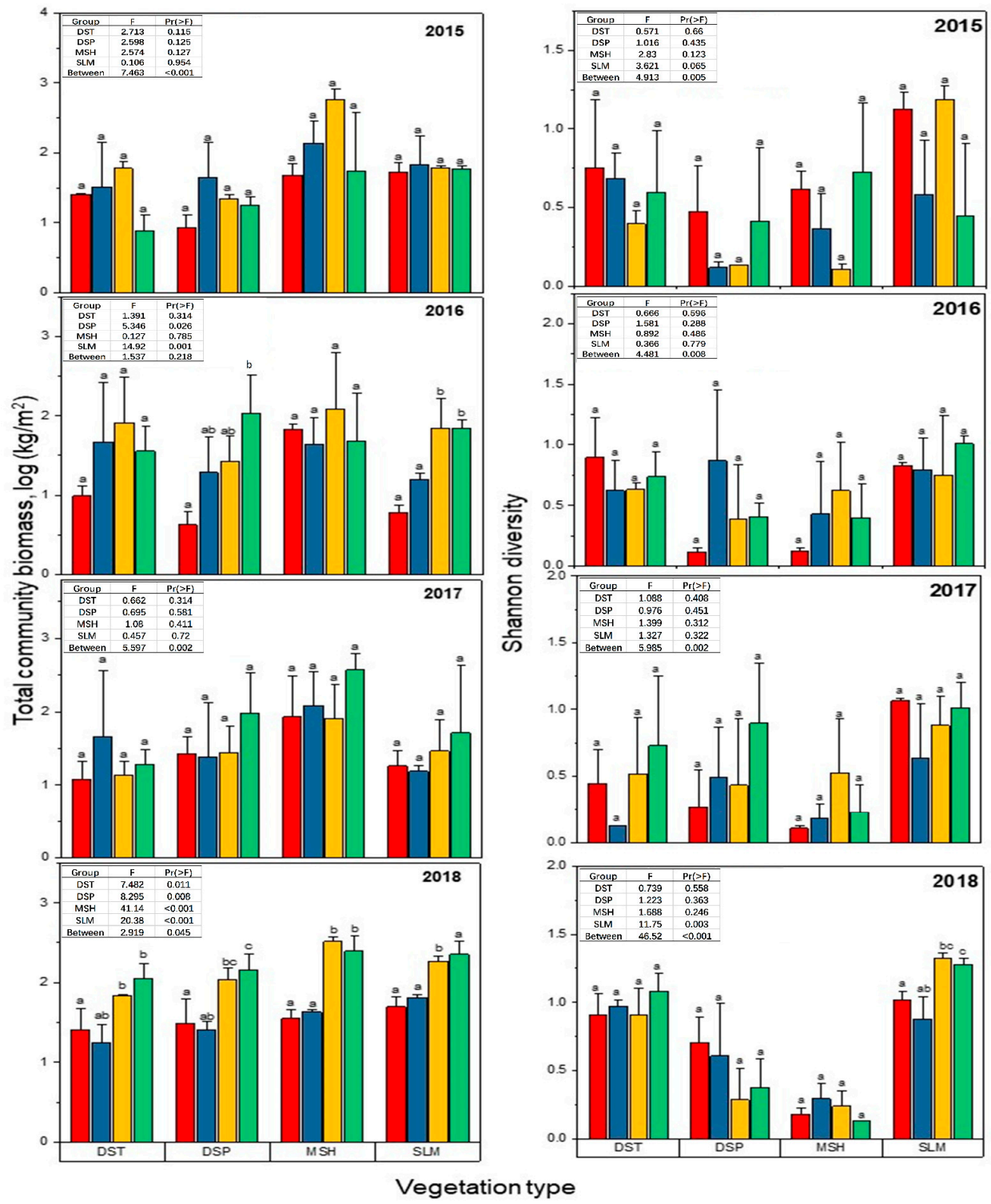

Figure 2. Response of total community aboveground biomass $\left(\mathrm{Kg} / \mathrm{m}^{2}\right)$ and Shannon diversity to nitrogen addition and experimental warming in desert (DST), desert steppe (DSP), marsh (MSH) and salinised meadow from 2015 to 2018. Treatments (within year) with the same letter are not significantly different. The different colour in the graph represents the experimental treatment, the red colour $=\mathrm{CK}$, blue colour $=\mathrm{N}$, yellow colour $=\mathrm{W}$ and green colour $=\mathrm{WN}$. 


\subsection{Interactions between Experimental Treatment and Sampling Year on Plant Community}

As shown in Table 1, the interaction between the sampling year and experimental treatment were observed regarding the coverage $(p<0.001)$ of the alpine desert. Sampling year alone had a significant effect on coverage $(p<0.05)$, height $(p<0.001)$, richness $(p<0.01)$, Shannon $(p<0.01)$ and Pielou indies $(p<0.001)$. Treatment alone only had a significant effect on coverage $(p<0.01)$ and height $(p<0.05)$.

Table 1. Two-way ANOVA for treatment (TRT) and year (YR) and their interactions on the measured variables for four vegetation types.

\begin{tabular}{|c|c|c|c|c|c|c|c|c|c|c|c|c|}
\hline \multirow{2}{*}{ Factors } & \multicolumn{6}{|c|}{ Desert } & \multicolumn{6}{|c|}{ Marsh } \\
\hline & Biomass & Coverage & Height & Richness & Shannon & Pielou & Biomass & Coverage & Height & Richness & Shannon & Pielou \\
\hline Year & 1.303 & $3.646^{*}$ & 7.118 & $5.376 * *$ & $5.566 * *$ & $8.747^{* * *}$ & 1.278 & $5.589 * *$ & 1.609 & 2.102 & 1.943 & 1.850 \\
\hline $\begin{array}{c}\text { TRT } \\
\text { Year } \times \text { TRT }\end{array}$ & $\begin{array}{l}1.966 \\
1.687\end{array}$ & $\begin{array}{l}5.228 * * \\
4.504 * * *\end{array}$ & $\begin{array}{l}2.935^{*} \\
1.843\end{array}$ & $\begin{array}{l}0.398 \\
1.807\end{array}$ & $\begin{array}{l}1.086 \\
0.737\end{array}$ & $\begin{array}{l}1.781 \\
0.695\end{array}$ & $\begin{array}{c}5.151 * * \\
1.680\end{array}$ & $\begin{array}{l}4.045^{*} \\
1.141\end{array}$ & $\begin{array}{c}0.311 \\
3.903\end{array}$ & $\begin{array}{l}1.309 \\
1.539\end{array}$ & $\begin{array}{l}0.469 \\
1.868\end{array}$ & $\begin{array}{l}0.706 \\
1.420\end{array}$ \\
\hline \multirow{2}{*}{ Factors } & \multicolumn{6}{|c|}{ Desert steppe } & \multicolumn{6}{|c|}{ Salinised meadow } \\
\hline & Biomass & Coverage & Height & Richness & Shannon & Pielou & Biomass & Coverage & Height & Richness & Shannon & Pielou \\
\hline Year & $3.445^{*}$ & $7.441^{* * *}$ & 1.107 & $5.576^{* *}$ & 0.918 & $2.204^{+}$ & $8.827^{* * *}$ & $3.808^{*}$ & $2.711^{+}$ & 15.317 & 2.719 & $2.751^{+}$ \\
\hline $\begin{array}{c}\text { TRT } \\
\text { Year } \times \text { TRT }\end{array}$ & $\begin{array}{c}6.583 * * \\
1.588\end{array}$ & $\begin{array}{l}5.985^{* *} \\
2.997^{*}\end{array}$ & $\begin{array}{l}1.401 \\
0.859\end{array}$ & $\begin{array}{c}0.580 \\
1.967^{+}\end{array}$ & $\begin{array}{l}0.885 \\
1.314\end{array}$ & $\begin{array}{l}1.016 \\
0.887\end{array}$ & $\begin{array}{c}6.786^{* *} \\
1.261\end{array}$ & $\begin{array}{l}0.396 \\
0.908\end{array}$ & $\begin{array}{l}1.782 \\
0.459\end{array}$ & $\begin{array}{l}1.936 \\
1.851\end{array}$ & $\begin{array}{c}3.056^{*} \\
1.951\end{array}$ & $\begin{array}{l}2.684^{+} \\
1.973^{+}\end{array}$ \\
\hline
\end{tabular}

Notes: $p<0.001={ }^{* * * \prime}, p<0.01={ }^{* * \prime}, p<0.05={ }^{* \prime \prime}, p<0.1={ }^{\prime}+{ }^{\prime}$. Biomass, coverage, height and richness were log-transformed to stabilise the variance before ANOVA was applied.

In the alpine marsh, interaction between the sampling year and experimental treatment was observed on the height $(p<0.01)$. Sampling year alone only had a significant effect on coverage $(p<0.01)$. Treatment alone only had a significant effect on biomass $(p<0.01)$ and coverage $(p<0.05)$.

In the alpine desert steppe, the interaction between the sampling year and experimental treatment were only observed regarding the coverage $(p<0.05)$. Sampling year alone had a significant effect on biomass $(p<0.05)$, coverage $(p<0.001)$ and richness $(p<0.01)$. Treatment alone only had a significant effect on biomass $(p<0.01)$ and coverage $(p<0.01)$.

In the salinised meadow, interaction between the sampling year and experimental treatment were not observed. Sampling year alone had a significant effect on biomass $(p<0.001)$, coverage $(p<0.05)$ and richness $(p<0.001)$. Treatment alone only had a significant effect on biomass $(p<0.01)$ and Shannon index $(p<0.05)$.

\subsection{Relationship among Plant Biomass, Coverage, Evenness, Height, Richness and Diversity}

Table 2 shows Pearson's Moment correlations for the community cover, aboveground plant biomass, species evenness, plant height, richness, Shannon diversity and Pielou index. Plant coverage showed a strong correlation with plant biomass $(r=0.45 ; p<0.05)$. Plant height had a strong correlation with aboveground biomass and coverage $(r=0.41, p<0.05$; $r=0.65, p<0.05$, respectively). There was a strong correlation between plant richness and aboveground biomass $(r=0.31 ; p<0.05)$, coverage $(r=0.59 ; p<0.05)$, and plant height $(r=0.43 ; p<0.05)$. There was no strong correlation between plant biomass with Shannon and Pielou indices. Shannon diversity positively correlated with plant height $(r=0.27$; $p<0.05)$. There was a strong positive correlation between Pielou evenness and height $(r=0.27 ; p<0.05)$ and Shannon diversity $(r=0.90 ; p<0.05)$. Pielou evenness has a strong association with richness $(r=-0.19 ; p<0.05)$ (Table 2). 
Table 2. Person's correlation test among plant community properties.

\begin{tabular}{ccccccc}
\hline Variables & Biomass & Coverage & Height & Richness & Shannon & Pielou \\
\hline Biomass & 1.00 & & & & & \\
Coverage & $0.45^{* *}$ & 1.00 & & & & \\
Height & $0.41^{* *}$ & $0.65^{* *}$ & 1.00 & & & \\
Richness & $0.31^{* *}$ & $0.59^{* *}$ & $0.43^{* *}$ & 1.00 & & \\
Shannon & -0.12 & -0.07 & $0.27^{* *}$ & -0.13 & 1.00 & \\
Pielou & -0.13 & -0.10 & $0.27^{* *}$ & $-0.19^{* *}$ & $0.90^{* *}$ & 1.00 \\
\hline
\end{tabular}

Note: ${ }^{* *}: p<0.05$. Biomass, coverage, height and richness were log-transformed.

\section{Discussion}

The responses of plant biomass and diversity to the changes occurring in an environment reflects the resilience of the plant community [34,49]. Our results showed that plant communities (alpine desert, alpine desert steppe, alpine marsh, and alpine salinised meadow) might respond differently to long-term warming and $\mathrm{N}$ deposition.

In this study, we observed that warming and warming combined with $\mathrm{N}$ deposition treatments stimulated the aboveground biomass of all vegetation types after the fouryear-long experiment (2015-2018). This suggested that long-term warming and warming combined with $\mathrm{N}$ deposition will increase vegetation productivity in alpine regions. This may be because alpine plant communities are usually limited by cold weather; thus, warming can favour the growth of plants in cold alpine regions. We also found that aboveground biomass increased more under the warming combined with $\mathrm{N}$ deposition treatment in the alpine salinised meadow, suggesting that $\mathrm{N}$ might still be a limiting factor for plant productivity in alpine salinised meadows. In the alpine desert, alpine desert steppe and alpine marsh, the positive effects of warming on plant biomass were more obvious, while the effects of $\mathrm{N}$ deposition were not significant, suggesting that temperature might be an important limiting factor in other vegetation types. Responses of plant communities to warming and $\mathrm{N}$ deposition usually vary with vegetation types [50]. Changes in aboveground plant biomass are central in understanding how nitrogen deposition $(\mathrm{N})$ and warming $(\mathrm{W})$ affect the productivity of alpine communities. In the present study, WN and $\mathrm{N}$ treatment only obviously increased the aboveground plant biomass of all vegetation types in 2018, suggesting that such effects might need a longer time to be evident. The variation differed across different vegetation types, indicating that the alpine plant communities' differential responses might be associated with the divergent adaptabilities of different alpine vegetation types to environmental changes $[11,12,50]$.

In this present study, we found that nitrogen deposition alone rarely increased aboveground biomass. This finding is consistent with the results found in the observation of the Wasatch Plateau by Gill (2014) [51]. In contrast, N deposition significantly increased plant aboveground biomass in a temperate old field [3]. The highest increase in plant biomass in the alpine salinised meadow was due to the combined effects of experimental warming and nitrogen deposition. This is consistent with a study that was carried out in the temperate grassland of Songnen Plain in northern China [11]. Though plant diversity decline might be attributed to warming in numerous experiments [52-55], our studies found that only the Shannon index of the alpine salinised meadow was increased under warming and warming combined with $\mathrm{N}$ deposition treatment after the four-year-long experiment. This suggested that the diversity of alpine desert, alpine desert steppe and alpine marsh is much more stable and may not be very susceptible to the influence of short-term (four years) warming and $\mathrm{N}$ depositionl other environmental factors, such as climatic variability (precipitation in particular), might indirectly affect co-existing species by altering the composition of the plant community [56]. However, in 2018, warming and warming combined with $\mathrm{N}$ deposition significantly increased the plant diversity of the alpine salinised meadow, indicating that the plant diversity of the alpine salinised meadow was more sensitive to short-term (four years) warming and warming combined with $\mathrm{N}$ deposition. This finding showed that $\mathrm{N}$ deposition alone had no obvious impacts on the 
species diversity of the alpine plant communities; large disparities might take a longer period ( $>4$ years) to become apparent [11,57].

Generally, there is a positive relationship between plant biomass and coverage [58-61], and this is consistent with our results. Our results also showed a strong positive relationship between biomass and plant cover. It has been reported that plant productivity in the alpine ecosystem is sensitive to environmental changes, especially temperature $[62,63]$. Our findings indicate a strong relationship between species diversity and plant productivity variables, which could be due to the unique characteristics of the grasslands.

\section{Conclusions}

Responses of the alpine plant communities varied with different vegetation types to warming, nitrogen deposition and warming plus nitrogen deposition over four years in the well-protected alpine area of the AMNR on the QTP. Long-term ( $>4$ years) warming and warming plus $\mathrm{N}$ deposition will significantly increase the productivity of alpine desert, alpine desert steppe, alpine marsh, and alpine salinised meadow. Long-term ( $>4$ years) warming and warming plus $\mathrm{N}$ deposition will significantly increase the plant community diversity of alpine salinised meadow. Short-term ( $\leq 4$ years) $\mathrm{N}$ deposition might have no significant effect on plant community productivity and diversity. No obvious interactions were found between warming and $\mathrm{N}$ deposition in the short term. Large disparities might take a longer period ( $>4$ years) to become apparent. Warming was shown to be essential in increasing the productivity of alpine vegetation, as the effect of the $\mathrm{N}$ deposition was minimal. These findings can further improve our understanding of how alpine vegetation reacts to changes in the environment and help us to have a better sustainable conservation management of alpine grassland in the future.

Supplementary Materials: The following are available online at https: / www.mdpi.com/article/10 .3390/plants10122719/s1, Figure S1: Truncated cone-shaped open top chamber schematic diagram.

Author Contributions: Conceptualization and methodology, S.D.; formal analysis, E.A.K.; investigation, E.A.K., W.L., W.S., X.S., Y.Z., S.L. (Shuai Li), X.G., S.L. (Shiliang Liu), J.S., X.L., Q.L., Z.Z.; data curation, E.A.K.; writing —original draft preparation, E.A.K.; writing—review and editing, E.A.K., H.S., S.D; visualization, E.A.K.; supervision, S.D.; funding acquisition, S.D. All authors have read and agreed to the published version of the manuscript.

Funding: This study was funded by the Second Tibetan Plateau Scientific Expedition and Research Program (2019QZKK0307), the National Science Foundation of China (U20A2007-01), Key R\&D Program of Qinghai Province (2019-SF-145 and 2018-NK-A2).

Institutional Review Board Statement: Not applicable.

Informed Consent Statement: Not applicable.

Data Availability Statement: All the data supporting this article were included in the main text.

Conflicts of Interest: The authors declare no conflict of interest.

\section{References}

1. IPCC Climate Change: The Physical Science Basis. Contribution of Working Group I to the Fifth Assessment Report of the Intergovenmental Panel on Climate Change; Cambridge University Press: Cambridge, UK; New York, NY, USA, 2013.

2. Vitousek, P.M.; Howarth, R.W. Nitrogen Limitation on Land and in the Sea: How Can It Occur? Biogeochemistry 1991, 13, 87-115. [CrossRef]

3. Hutchison, J.S.; Henry, H.A.L. Additive effects of warming and increased nitrogen deposition in a temperate old field: Plant productivity and the importance of winter. Ecosystems 2010, 13, 661-672. [CrossRef]

4. Zhang, M.; Song, C.; Kühn, P.; Shi, Y.; He, J.-S.; Scholten, T.; Baumann, F.; Geng, Y. Increasing temperature reduces the coupling between available nitrogen and phosphorus in soils of Chinese grasslands. Sci. Rep. 2017, 7, 1-10. [CrossRef]

5. Guntiñas, M.E.; Leirós, M.C.; Trasar-cepeda, C.; Gil-sotres, F. Effects of moisture and temperature on net soil nitrogen mineralization: A laboratory study. Eur. J. Soil Biol. 2012, 48, 73-80. [CrossRef]

6. Zeller, V.; Bahn, M.; Aichner, M.; Tappeiner, U. Impact of land-use change on nitrogen mineralization in subalpine grasslands in the Southern Alps. Biol. Fertil. Soils 2000, 31, 441-448. [CrossRef] 
7. Yang, L.; Zhang, F.; Gao, Q.; Mao, R.; Liu, X. Impact of land-use types on soil nitrogen net mineralization in the sandstorm and water source area of Beijing, China. CATENA 2010, 82, 15-22. [CrossRef]

8. Bedard-Haughn, A.; Matson, A.L.; Pennock, D.J. Land use effects on gross nitrogen mineralization, nitrification, and N2O emissions in ephemeral wetlands. Soil Biol. Biochem. 2006, 38, 3398-3406. [CrossRef]

9. Boutin, M.; Corcket, E.; Alard, D.; Villar, L.; Corriol, G.; Lamaze, T.; Blaix, C. Nitrogen deposition and climate change have increased vascular plant species richness and altered the composition of grazed subalpine grasslands J. Ecol. 2017, 1199-1209. [CrossRef]

10. Standish, R.J.; Fontaine, J.B.; Harris, R.J.; Stock, W.D.; Hobbs, R.J. Interactive effects of altered rainfall and simulated nitrogen deposition on seedling establishment in a global biodiversity hotspot. Oikos 2012, 121, 2014-2025. [CrossRef]

11. Zhang, T.; Guo, R.; Gao, S.; Guo, J.; Sun, W. Responses of Plant Community Composition and Biomass Production to Warming and Nitrogen Deposition in a Temperate Meadow Ecosystem. PLoS ONE 2015, 10, e0123160. [CrossRef]

12. Zavaleta, E.S.; Shaw, M.R.; Chiariello, N.R.; Mooney, H.A.; Field, C.B. Additive effects of simulated climate changes, elevated CO2, and nitrogen deposition on grassland diversity. Proc. Natl. Acad. Sci. USA 2003, 100, 7650-7654. [CrossRef] [PubMed]

13. Zhang, Y.; Lü, X.; Isbell, F.; Stevens, C.; Han, X.; He, N.; Zhang, G.; Yu, Q.; Huang, J.; Han, X. Rapid plant species loss at high rates and at low frequency of $\mathrm{N}$ addition in temperate steppe. Glob. Chang. Biol. 2014, 20, 3520-3529. [CrossRef] [PubMed]

14. Simkin, S.M.; Allen, E.B.; Bowman, W.D.; Clark, C.M.; Belnap, J.; Brooks, M.L.; Cade, B.S.; Collins, S.L.; Geiser, L.H.; Gilliam, F.S.; et al. Conditional vulnerability of plant diversity to atmospheric nitrogen deposition across the United States. Proc. Natl. Acad. Sci. USA 2016, 113, 4086-4091. [CrossRef] [PubMed]

15. Wang, D.; He, H.L.; Gao, Q.; Zhao, C.Z.; Zhao, W.Q.; Yin, C.Y.; Chen, X.; Ma, Z.L.; Li, D.D.; Sun, D.D.; et al. Effects of short-term $\mathrm{N}$ addition on plant biomass allocation and $\mathrm{C}$ and $\mathrm{N}$ pools of theSibiraea angustatascrub ecosystem. Eur. J. Soil Sci. 2017, 68, 212-220. [CrossRef]

16. Bobbink, R.; Hornung, M.; Roelofs, J.G.M. The effects of air-borne nitrogen pollutants on species diversity in natural and semi-natural European vegetation. J. Ecol. 1998, 86, 717-738. [CrossRef]

17. Roth, T.; Kohli, L.; Rihm, B.; Amrhein, V.; Achermann, B. Nitrogen deposition and multi-dimensional plant diversity at the landscape scale. R. Soc. Open Sci. 2015, 2, 150017. [CrossRef]

18. Thomas, J.A. Comparative Losses of British Butterflies, Birds, and Plants and the Global Extinction Crisis. Science 2004, 303, 1879-1881. [CrossRef] [PubMed]

19. Stevens, C.J.; Dise, N.B.; Gowing, D.J.G.; Mountford, J.O. Loss of forb diversity in relation to nitrogen deposition in the UK: Regional trends and potential controls. Glob. Chang. Biol. 2006, 12, 1823-1833. [CrossRef]

20. Tian, H.; Melillo, J.; Lu, C.; Kicklighter, D.; Liu, M.; Ren, W.; Xu, X.; Chen, G.; Zhang, C.; Pan, S.; et al. China's terrestrial carbon balance: Contributions from multiple global change factors. Glob. Biogeochem. Cycles 2011, 25. [CrossRef]

21. Sala, O.E.; Kinzig, A.; Leemans, R.; Lodge, D.M.; Mooney, H.A.; Oesterheld, M.; Poff, N.L.; Sykes, M.T.; Walker, B.H.; Walker, M.; et al. Biodiversity-Global biodiversity scenarios for the year 2100. Science 2000, 287, 1770-1774. [CrossRef]

22. Hoffmann, M.; Hilton-Taylor, C.; Angulo, A.; Böhm, M.; Brooks, T.M.; Butchart, S.H.M.; Carpenter, K.E.; Chanson, J.; Collen, B.; Cox, N.A.; et al. The Impact of Conservation on the Status of the World's Vertebrates. Science 2010, 330, 1503-1509. [CrossRef]

23. He, K.; Qi, Y.; Huang, Y.; Chen, H.; Sheng, Z.; Xu, X.; Duan, L. Response of aboveground biomass and diversity to nitrogen addition-A five-year experiment in semi-arid grassland of Inner Mongolia, China. Sci. Rep. 2016, 6, 31919. [CrossRef] [PubMed]

24. Shen, H.; Dong, S.; Li, S.; Xiao, J.; Han, Y.; Yang, M.; Zhang, J.; Gao, X.; Xu, Y.; Li, Y.; et al. Effects of simulated N deposition on photosynthesis and productivity of key plants from different functional groups of alpine meadow on Qinghai-Tibetan plateau. Environ. Pollut. 2019, 251, 731-737. [CrossRef] [PubMed]

25. Verma, P.; Sagar, R.; Verma, H.; Verma, P.; Singh, D.K. Changes in species composition, diversity and biomass of herbaceous plant traits due to $\mathrm{N}$ amendment in a dry tropical environment of India. J. Plant Ecol. 2014, 8, 321-332. [CrossRef]

26. Wan, S.; Hui, D.; Wallace, L.; Luo, Y. Direct and indirect effects of experimental warming on ecosystem carbon processes in a tallgrass prairie. Glob. Biogeochem. Cycles 2005, 19, 1-13. [CrossRef]

27. Klein, J.A.; Harte, J.; Zhao, X.-Q. Experimental Warming, Not Grazing, Decreases Rangeland Quality On The Tibetan Plateau. Ecol. Appl. 2007, 17, 541-557. [CrossRef] [PubMed]

28. Xu, X.; Sherry, R.A.; Niu, S.; Li, D.; Luo, Y. Net primary productivity and rain-use efficiency as affected by warming, altered precipitation, and clipping in a mixed-grass prairie. Glob. Chang. Biol. 2013, 19, 2753-2764. [CrossRef]

29. Lu, C.; Tian, H. Spatial and temporal patterns of nitrogen deposition in China: Synthesis of observational data. J. Geophys. Res. Space Phys. 2007, 112. [CrossRef]

30. Dong, S.; Sherman, R. Enhancing the resilience of coupled human and natural systems of alpine rangelands on the Qinghai-Tibetan Plateau. Rangel. J. 2015, 37. [CrossRef]

31. Li, Y.; Dong, S.; Liu, S.; Zhou, H.; Gao, Q.; Cao, G.; Wang, X.; Su, X.; Zhang, Y.; Tang, L.; et al. Seasonal changes of CO2, CH4 and $\mathrm{N} 2 \mathrm{O}$ fluxes in different types of alpine grassland in the Qinghai-Tibetan Plateau of China. Soil Biol. Biochem. 2014, 80, 306-314. [CrossRef]

32. Fu, G.; Shen, Z.-X. Response of Alpine Plants to Nitrogen Addition on the Tibetan Plateau: A Meta-analysis. J. Plant Growth Regul. 2016, 35, 974-979. [CrossRef] 
33. Han, Y.; Dong, S.; Zhao, Z.; Sha, W.; Li, S.; Shen, H.; Xiao, J.; Zhang, J.; Wu, X.; Jiang, X.; et al. Response of soil nutrients and stoichiometry to elevated nitrogen deposition in alpine grassland on the Qinghai-Tibetan Plateau. Geoderma 2019, 343, 263-268. [CrossRef]

34. Dong, S.; Shang, Z.; Gao, J.; Boone, R.B. Enhancing sustainability of grassland ecosystems through ecological restoration and grazing management in an era of climate change on Qinghai-Tibetan Plateau. Agric. Ecosyst. Environ. 2019, 287, 106684. [CrossRef]

35. Fu, G.; Zhang, X.; Zhang, Y.; Shi, P.; Li, Y.; Zhou, Y.; Yang, P.; Shen, Z. Experimental warming does not enhance gross primary production and above-ground biomass in the alpine meadow of Tibet. J. Appl. Remote. Sens. 2013, 7, 073505. [CrossRef]

36. Gao, Q.; Guo, Y.; Xu, H.; Ganjurjav, H.; Li, Y.; Wan, Y.; Qin, X.; Ma, X.; Liu, S. Climate change and its impacts on vegetation distribution and net primary productivity of the alpine ecosystem in the Qinghai-Tibetan Plateau. Sci. Total. Environ. 2016, 554-555, 34-41. [CrossRef] [PubMed]

37. Peng, Y.F.; Li, F.; Zhou, G.Y.; Fang, K.; Zhang, D.Y.; Li, C.B.; Yang, G.B.; Wang, G.Q.; Wang, J.; Yang, Y.H. Linkages of plant stoichiometry to ecosystem production and carbon flfluxes with increasing nitrogen inputs in an alpine steppe. Global Chang. Biol. 2017, 23, 5249-5259. [CrossRef]

38. Zong, N.; Chai, X.; Shi, P.L.; Yang, X.C. Effffects of warming and nitrogen addition on plant photosynthate partitioning in an Alpine Meadow on the Tibetan Plateau. J. Plant Growth Regul. 2018, 37, 803-812. [CrossRef]

39. Zhang, Y.; Dong, S.; Gao, Q.; Ganjurjav, H.; Wang, X.; Geng, W. "Rare biosphere” plays important roles in regulating soil available nitrogen and plant biomass in alpine grassland ecosystems under climate changes. Agric. Ecosyst. Environ. 2018, 279, 187-193. [CrossRef]

40. Wu, H.; Guo, Z.; Peng, C. Land use induced changes of organic carbon storage in soils of China. Glob. Chang. Biol. 2003, 9, 305-315. [CrossRef]

41. Yu, C.; Zhang, Y.; Claus, H.; Zeng, R.; Zhang, X.; Wang, J. Ecological and Environmental Issues Faced by a Developing Tibet. Environ. Sci. Technol. 2012, 46, 1979-1980. [CrossRef]

42. Fu, Y.-H.; Lu, R.-Y.; Guo, D. Changes in surface air temperature over China under the 1.5 and $2.0^{\circ} \mathrm{C}$ global warming targets. Adv. Clim. Chang. Res. 2018, 9, 112-119. [CrossRef]

43. Marion, G.M.; Henry, G.H.R.; Freckman, D.W.; Johnstone, J.; Jones, G.; Jones, M.H.; Lévesque, E.; Molau, U.; Mølgaard, P.; Parsons, A.N.; et al. Open-top designs for manipulating field temperature in high-latitude ecosystems. Glob. Chang. Biol. 1997, 3, 20-32. [CrossRef]

44. Samson, M.; Słowińska, S.; Słowiński, M.; Lamentowicz, M.; Barabach, J.; Harenda, K.; Zielińska, M.; Robroek, B.; Jassey, V.; Buttler, A.; et al. The Impact of Experimental Temperature and Water Level Manipulation on Carbon Dioxide Release in a Poor Fen in Northern Poland. Wetlands 2018, 38, 551-563. [CrossRef]

45. Lamentowicz, M.; Słowińska, S.; Słowiński, M. Combining short-term manipulative experiments with long-term palaeoecological investigations at high resolution to assess the response of Sphagnum peatlands to drought, fire and warming. Mires Peat 2016, 18, 1-17. [CrossRef]

46. Shaver, G.R.; Canadell, J.; Chapin, F.S.; Gurevitch, J.; Harte, J.; Henry, G.H.R.; Ineson, P.; Jonasson, S.; Melillo, J.M.; Pitelka, L.F.; et al. Global Warming and Terrestrial Ecosystems: A Conceptual Framework for Analysis. BioScience 2000, 50, 871-882. [CrossRef]

47. Ren, J.Z. Methods in Grassland Science; China Agricultural Press: Beijing, China, 1998.

48. Shannon, C.E.; Weaver, W. The Mathematical Theory of Communication; The University of Illinois Press: Urbana, IL, USA, 1963.

49. Raiesi, F.; Riahi, M. The influence of grazing exclosure on soil C stocks and dynamics, and ecological indicators in upland arid and semi-arid rangelands. Ecol. Indic. 2014, 41, 145-154. [CrossRef]

50. Song, L.; Bao, X.; Liu, X.; Zhang, F. Impact of nitrogen addition on plant community in a semi-arid temperate steppe in China. J. Arid. Land 2012, 4, 3-10. [CrossRef]

51. Gill, R.A. The influence of 3-years of warming and N-deposition on ecosystem dynamics is small compared to past land use in subalpine meadows. Plant Soil 2013, 374, 197-210. [CrossRef]

52. Botkin, D.B.; Saxe, H.; Araújo, M.B.; Betts, R.; Bradshaw, R.; Cedhagen, T.; Chesson, P.; Dawson, T.; Etterson, J.; Faith, D.P.; et al. Forecasting the Effects of Global Warming on Biodiversity. BioScience 2007, 57, 227-236. [CrossRef]

53. Chapin, F.S.; Shaver, G.R.; Giblin, A.E.; Nadelhoffer, K.J.; Laundre, J.A. Responses of Arctic Tundra to Experimental and Observed Changes in Climate. Ecology 1995, 76, 694-711. [CrossRef]

54. Klein, J.A.; Harte, J.; Zhao, X.-Q. Experimental warming causes large and rapid species loss, dampened by simulated grazing, on the Tibetan Plateau. Ecol. Lett. 2004, 7, 1170-1179. [CrossRef]

55. Zhang, Y.; Dong, S.K.; Gao, Q.Z.; Liu, S.L.; Zhou, H.K.; Ganjurjav, H.; Wang, X.X. Climate change and human activities altered the diversity and composition of soil microbial community in alpine grasslands of the Qinghai-Tibetan Plateau. Sci. Total Environ. 2016, 562, 353-363. [CrossRef] [PubMed]

56. Engel, E.C.; Weltzin, J.F.; Norby, R.J.; Classen, A.T. Responses of an old-field plant community to interacting factors of elevated [CO2], warming, and soil moisture. J. Plant Ecol. 2009, 2, 1-11. [CrossRef]

57. Pennings, S.C.; Clark, C.M.; Cleland, E.E.; Collins, S.L.; Gough, L.; Gross, K.L.; Milchunas, D.G.; Suding, K.N. Do individual plant species show predictable responses to nitrogen addition across multiple experiments? OIKOS 2005, 3, 547-555. [CrossRef]

58. Jiang, Z.-Y.; Li, X.-Y.; Wu, H.-W.; Zhang, S.-Y.; Zhao, G.-Q.; Wei, J.-Q. Linking spatial distributions of the patchy grass Achnatherum splendens with dynamics of soil water and salt using electromagnetic induction. CATENA 2017, 149, 261-272. [CrossRef] 
59. Li, Y.; Dong, S.; Liu, S.; Su, X.; Wang, X.; Zhang, Y.; Zhao, Z.; Gao, X.; Li, S.; Tang, L. Relationships between plant diversity and biomass production of alpine grasslands are dependent on the spatial scale and the dimension of biodiversity. Ecol. Eng. 2018, 127, 375-382. [CrossRef]

60. Zhao, Y.; Wang, X.; Ou, Y.; Jia, H.; Li, J.; Shi, C.; Liu, Y. Variations in soil $\delta 13 \mathrm{C}$ with alpine meadow degradation on the eastern Qinghai-Tibet Plateau. Geoderma 2018, 338, 178-186. [CrossRef]

61. Zhang, L.; Cui, G.; Shen, W.; Liu, X. Cover as a simple predictor of biomass for two shrubs in Tibet. Ecol. Indic. 2016, 64, 266-271. [CrossRef]

62. Liu, M.; Liu, G.; Gong, L.; Wang, D.; Sun, J. Relationships of Biomass with Environmental Factors in the Grassland Area of Hulunbuir, China. PLoS ONE 2014, 9, e102344. [CrossRef]

63. Dorji, T.; Moe, S.R.; Klein, J.A.; Totland, Ø. Plant Species Richness, Evenness, and Composition along Environmental Gradients in an Alpine Meadow Grazing Ecosystem in Central Tibet, China. Arct. Antarct. Alp. Res. 2014, 46, 308-326. [CrossRef] 